\title{
PERSPECTIVES OF TECHNICAL EDUCATION DEVELOPMENT FOR STUDENTS WITH MILD MENTAL DISABILITIES
}

Aleš BARTO $\check{N}^{*}$, ZŠ a MŠ Křemže; VŠERS, z. ú., Česká republika

Přijato: 14. 2. 2017 / Akceptováno: 14. 3. 2017

Typ článku: Výzkumná studie

DOI: $10.5507 /$ jtie.2017.010

Abstract: This paper deals with possible perspectives for the educational area Man and the World of Work, resulting from the gradual introduction of common education. Some of them were described by means of the content analysis and subsequent comparison of the Framework Education Programme for Elementary Education (2016), other information sources and the already expired Annex modifying the education of pupils with mild mental disabilities (2005). For the purposes of exploratory survey the quantitative approach was used, whereby it was found that the inclusive education affects amount of the time allocation for the educational area Man and the World of Work.

Key words: available time allocation, key competencies, light mental disability, expected outputs, supportive measures, joint education (inclusion).

\section{PERSPEKTIVY ROZVOJE TECHNICKÉHO VZDĚLÁVÁNÍ U ŽÁKŮ S LEHKÝM MENTÁLNÍM POSTIŽENÍM}

Abstrakt: Př́spěvek se zabývá možnými perspektivami pro vzdělávací oblast Člověk a svět práce, které vyplývají z postupného zavádění společného vzdělávání. Prostřednictvím obsahové analýzy a následné komparace Rámcového vzdělávacího programu pro základní vzdělávání (2016), dalších informačních zdrojů a dnes již neplatné Př́lohy upravující vzdělávání žákủ s lehkým mentálním postižením (2005) byly některé z nich popsány. Pro potřeby průzkumného šetření byl použit kvantitativní přístup, v rámci něhož bylo zjišsěno, že inkluzivní vzdělávání ovlivňuje výši časové dotace pro vzdělávací oblast Člověk a svět práce.

Klíčová slova: disponibilní časová dotace, klíčové kompetence, lehké mentální postižení, očekávané výstupy, podpůrné opatření, společné vzdělávání (inkluze).

*Autor pro korespondenci: barton@ vsers.cz 


\section{1 Úvod}

V souvislosti s nezadržitelným rozvojem lidské společnosti se mění i její politické a sociální uspořádání, které stále více klade důraz na posilování konkurenceschopnosti, tedy adaptability pracovních sil na základě rovného př́stupu bez ohledu na predikci deficitu, např́klad prostřednictvím rozvoje specifických dovedností, př́stupu $\mathrm{k}$ vědomostem, informacím a schopnosti těchto zdrojů využívat ve svůj prospěch díky technice. Jedná se vlastně o proces celoživotního učení, který jde ruku v ruce s řadou akcentovaných požadavků, např. na technicky gramotného člověka ve 21. století, viz The new Skills Agenda for Europe (2016); Memorandum o celoživotním učení (Zpravodaj, př́loha II/2001); Strategie pro vzdělávání pro udržitelný rozvoj (2005). Vzdělávání v oblasti techniky sehrává pro naplnění tohoto požadavku jistě důležitou úlohu.

V Rámcovém vzdělávacím programu pro základní vzdělávání (RVP ZV) je zastoupeno Vzdělávací oblastí Člověk a svět práce (ČSP), která vede k utváření a rozvíjení klíčových kompetencí (KK) v návaznosti na vzdělávací obsah prostréednictvím specifických činností (Mach, Simbartl, Krotký, 2015). Ty jsou typické právě pro tuto vzděl. oblast díky tomu, že integruje řadu vědních oborů (př́rodovědné, matematické, společenské aj.) a zároveň se odlišuje od ostatních vzdělávacích oblastí svojí orientací na praktický nácvik (praktickou činnost), která je pro řadu žáků se speciálními vzdělávacími potřebami (SVP) esenciální. Rovněž lze v této souvislosti vyzdvihnout předpoklad pro „aktivní se učení žáka“ propojením formálního, neformálního a informálního vzdělávání (Částková, Kropáč, Plischke, 2016). Právě specifičnost dosahování KK odlišuje tento vzdělávací obor od ostatních.

Jako zásadní se proto jeví zrušení př́lohy RVP ZV, která upravovala vzdělávání žáků s lehkým mentálním postižením (LMP) ve třídách, odděleních nebo studijních skupinách, které jsou zřízeny podle $\S 16$ odst. 9 ŠZ (dřive ZŠP - základní škola praktická) nebo ve škole, třídě oddělení nebo studijní skupině, která není zrrízena podle $\S 16$ (běžné ZŠ). V praxi to znamená úpravy nebo vydání zcela nových školních vzdělávacích programů (ŠVP) v souladu s RVP ZV všech škol. Vyvstávají tak nové perspektivy, které vyplývají z proinkluzivních př́stupů a mohou mít na kvalitu edukace jak pozitivní, tak negativní dopad. Právě některé z nich se snažíme v kontextu vzdělávací oblasti ČSP v tomto článku postihnout.

\section{Použité metody}

Prostřednictvím kvantitativního přístupu byla provedena obsahová analýza Rámcového učebního plánu (RUP) a Vzdělávací oblasti ČSP obsažených v RVP ZV LMP (2005) a RVP ZV (2016). Následnou komparací těchto dokumentů v kontextu dalších informačních zdrojů a aktuálních trendů byly popsány některé z perspektiv, které mohou ovlivnit kvalitu dosahování KK u žáků s LMP. Jako výzkumná metoda pro potřeby průzkumného šetření byl zvolen nestandardizovaný dotazník, který sestával z uzavřených a otevřených otázek. Ve vybraných př́padech byl doplněn o metodu neformálního rozhovoru a strukturovaného rozhovoru s otevřenými otázkami.

V rámci šetření bylo osloveno všech 18 veřejných škol zřízených podle $\S 16$, jejichž zřizovatelem je na území jižních Čech Krajský úřad Jihočeského kraje (viz Rejstř́k škol). Záměrně nebyla oslovena škola při dětské léčebně, protože její RUP je s ohledem na zdravotní potřeby klientů odlišný. S provedením průzkumného šetření souhlasilo 16 škol. Podmínkou pro porovnání časové dotace bylo to, aby měla škola svůj Školní vzdělávací 
program (ŠVP) upravený v souladu s RVP ZV nebo měla představu o časové dotaci svého nově tvořeného ŠVP. Časová dotace podle individuálního vzdělávacího plánu (IVP) nebyla zjištována, protože na učební plán (UP) nemá vliv. Nadále bylo proto pracováno pouze s daty z 11 škol. 4 školy totiž ještě neměly představu o časové dotaci pro tuto vzdělávací oblast. Důvodem je zvažování možné transformace na jiný typ školy nebo zaměření předmětu své činnosti na jiný druh postižení, popřípadě panující nejasnosti o další existenci. Jiná škola nejprve souhlasila s provedením průzkumu, pokud bude o měsíc odložen, ale nakonec se vlastního šetření nezúčastnila.

\section{Vzdělávací oblast Člověk a svět práce v kontextu inkluze}

Zrušení prílohy upravující vzdělávání žáků s LMP a její nahrazení RVP ZV $s$ upravenými očekávanými výstupy (OV) a odlišným cílovým zaměřením KK u vzdělávacích oblastí se projevilo i v úpravě RUP, podle kterého byli před novelou ŠZ žáci s LMP, popř. vícečetným postižením, vzděláváni. $Z$ tabulky 1 je patrné, že změna v časové dotaci se dotkla všech vzdělávacích oblastí a že zde vzniknul prostor k posílení měkkých dovedností (soft skills).

\begin{tabular}{|c|c|c|c|c|c|c|c|}
\hline \multicolumn{4}{|c|}{ RVP - LMP (2005) - RUP } & \multicolumn{4}{|c|}{ RVP - ZV (2016) - RUP } \\
\hline \multirow{3}{*}{$\begin{array}{l}\text { Vzděl. } \\
\text { oblast }\end{array}$} & \multirow{3}{*}{ Vzděl. obor } & 1. st. & 2. st. & \multirow{3}{*}{$\begin{array}{l}\text { Vzděl. } \\
\text { oblast }\end{array}$} & \multirow{3}{*}{ Vzděl. obor } & 1. st. & 2. st. \\
\hline & & $1-5 . \mathrm{r}$. & 6.-9. r. & & & $1-5 . r$ & 6-9. r. \\
\hline & & \multicolumn{2}{|c|}{ Min. čas. dotace } & & & \multicolumn{2}{|c|}{ Min. čas. dotace } \\
\hline \multirow{3}{*}{$\begin{array}{l}\text { Jazyk a } \\
\text { jazyková } \\
\text { kom. }\end{array}$} & $\begin{array}{l}\text { Český jaz. } \\
\text { a lit. }\end{array}$ & 33 & 19 & \multirow{3}{*}{$\begin{array}{l}\text { Jazyk a } \\
\text { jazyková } \\
\text { kom. }\end{array}$} & $\begin{array}{l}\text { Český jaz. } \\
\text { a lit. }\end{array}$ & 33 & 15 \\
\hline & Cizí jazyk & - & 4 & & Cizí jazyk & 9 & 12 \\
\hline & - & - & - & & Dal. c. jaz. & - & 6 \\
\hline \multicolumn{2}{|c|}{ Mat. a její aplikace } & 22 & 20 & \multicolumn{2}{|c|}{ Mat. a její aplikace } & 20 & 15 \\
\hline \multicolumn{2}{|c|}{ Inf. a kom. technologie } & 2 & 4 & \multicolumn{2}{|c|}{ Inf. a kom. technologie } & 1 & 1 \\
\hline \multicolumn{2}{|c|}{ Člověk a jeho svět } & 12 & - & \multicolumn{2}{|c|}{ Člověk a jeho svět } & 12 & - \\
\hline \multirow{2}{*}{$\begin{array}{l}\text { Člověk a } \\
\text { spol. }\end{array}$} & Dějepis & \multirow[b]{2}{*}{-} & \multirow[b]{2}{*}{11} & \multirow{2}{*}{$\begin{array}{l}\text { Člověk a } \\
\text { spol. }\end{array}$} & Dějepis & \multirow[b]{2}{*}{ - } & \multirow[b]{2}{*}{11} \\
\hline & $\begin{array}{l}\text { Vých. k } \\
\text { občanství }\end{array}$ & & & & $\begin{array}{l}\text { Vých. k } \\
\text { občanství }\end{array}$ & & \\
\hline \multirow{4}{*}{$\begin{array}{l}\text { Člověk a } \\
\text { př́roda }\end{array}$} & Fyzika & - & \multirow{4}{*}{13} & \multirow{4}{*}{$\begin{array}{l}\text { Člověk a } \\
\text { příroda }\end{array}$} & Fyzika & - & \multirow{4}{*}{21} \\
\hline & Chemie & - & & & Chemie & - & \\
\hline & Přírodopis & - & & & Prúrodopis & - & \\
\hline & Zeměpis & - & & & Zeměpis & - & \\
\hline \multirow{2}{*}{$\begin{array}{l}\text { Umění a } \\
\text { kultura }\end{array}$} & Hud. vých. & \multirow{2}{*}{10} & \multirow{2}{*}{8} & \multirow{2}{*}{$\begin{array}{l}\text { Umění a } \\
\text { kultura }\end{array}$} & Hud. vých. & \multirow{2}{*}{12} & \multirow{2}{*}{10} \\
\hline & Výt. vých. & & & & Výt. vých. & & \\
\hline \multirow{2}{*}{$\begin{array}{l}\text { Člověk a } \\
\text { zdraví }\end{array}$} & $\begin{array}{l}\text { Vých. ke } \\
\text { zdraví }\end{array}$ & - & 2 & \multirow{2}{*}{$\begin{array}{l}\text { Člověk a } \\
\text { zdraví }\end{array}$} & $\begin{array}{l}\text { Vých. ke } \\
\text { zdraví }\end{array}$ & - & 10 \\
\hline & $\begin{array}{l}\text { Těl. } \\
\text { výchova }\end{array}$ & 15 & 12 & & $\begin{array}{l}\text { Těl. } \\
\text { výchova }\end{array}$ & 10 & 10 \\
\hline $\begin{array}{l}\text { Čl. a svět } \\
\text { práce }\end{array}$ & $\begin{array}{l}\text { Člověk a } \\
\text { svět práce }\end{array}$ & 15 & 20 & $\begin{array}{l}\text { Čl. a svět } \\
\text { práce }\end{array}$ & $\begin{array}{l}\text { Člověk a } \\
\text { svět práce }\end{array}$ & 5 & 3 \\
\hline Disponibi & í čas. dotace & 9 & 12 & Disponibil & čas. dotace & 16 & 18 \\
\hline $\begin{array}{l}\text { Celková p } \\
\text { dotace }\end{array}$ & vinná časová & 118 & 122 & $\begin{array}{l}\text { Celková p } \\
\text { dotace }\end{array}$ & inná časová & 118 & 122 \\
\hline
\end{tabular}

Tabulka č. 1: Rámcový učebni plán dle RVP ZV a př́lohy LMP 
Úprava se dotkla nejvíce vzdělávací oblasti ČSP, kde byla minimální časová dotace na 1. stupni redukována z 15 hodin na 5 a v prípadě 2 . stupně z 20 hodin na 3 . Naopak u vzdělávací oblasti Jazyk jazyková komunikace došlo k zásadnímu posílení časové dotace pro výuku dalšího cizího jazyka. $Z$ původních 4 hodin realizované výuky na 2 . stupni na 9 hodin pro 1 . stupeň a 18 hodin pro 2 . stupeň.

Cílové zaměření vzdělávací oblasti ČSP RVP ZV již deficit LMP v návaznosti na osvojované a rozvíjené KK nezohledňuje, což samozřejmě klade v důsledku vyšší nároky na erudovanost pedagogických pracovníků a individuální prrístup. Rovněž nezmiňuje nutnost dodržovat hygienická a bezpečností pravidla při práci, což by mělo být pro všechny žáky bez ohledu na prípadné specifické vzdělávací potřeby zásadní. To je patrné z tabulky 2 .

\begin{tabular}{|c|c|}
\hline $\begin{array}{l}\text { Cílové zaměření vede k naplňování } \\
\text { KK tím, že vede k (RVP ZV - LMP } \\
\text { 2005, str. 62): }\end{array}$ & $\begin{array}{l}\text { Cílové zaměření vede k naplňování KK } \\
\text { tím, že vede k (RVP ZV 2016, str. 103): }\end{array}$ \\
\hline $\begin{array}{l}\text { pozitivnímu vztahu k práci a jejím výsledkům; } \\
\text { k práci v kolektivu a odpovědnosti za své } \\
\text { i společné výsledky práce }\end{array}$ & $\begin{array}{l}\text { pozitivnímu vztahu k práci a k odpovědnosti za } \\
\text { kvalitu svých i společných výsledků práce }\end{array}$ \\
\hline $\begin{array}{l}\text { rozvoji motoriky, získání základních } \\
\text { manuálních zručností a vytváření pracovních } \\
\text { dovedností a návyků z různých pracovních } \\
\text { oblastí, porozumění pojmưm, návodům, } \\
\text { orientaci v jednoduché technické dokumentaci, } \\
\text { zvládnutí pracovních postupů a dovednosti } \\
\text { řešit nejrůznější praktické situace }\end{array}$ & $\begin{array}{l}\text { osvojení základních pracovních dovedností } \\
\text { a návyků } \mathrm{z} \text { různých pracovních oblastí, } \\
\mathrm{k} \text { organizaci a plánování práce a } \mathrm{k} \text { použivání } \\
\text { vhodných nástrojů, nářadí a pomůcek při práci } \\
\text { i v běžném životě }\end{array}$ \\
\hline $\begin{array}{l}\text { orientaci v různých oborech lidské činnosti } \\
\text { a osvojení potřebných poznatků a dovedností } \\
\text { pro uplatnění př volbě povolání } \\
\text { a společenském uplatnění }\end{array}$ & $\begin{array}{l}\text { orientaci v různých oborech lidské činnosti, } \\
\text { formách fyzické a duševní práce a osvojení } \\
\text { potřebných poznatků a dovedností významných } \\
\text { pro možnost uplatnění, pro volbu vlastního } \\
\text { profesního zaměření a pro další životní } \\
\text { a profesní orientaci }\end{array}$ \\
\hline $\begin{array}{l}\text { poznání pracovních činností, které napomáhají } \\
\text { vytváření možných zálib a využití volného } \\
\text { času }\end{array}$ & $\begin{array}{l}\text { chápání práce a pracovní činnosti jako } \\
\text { př́ležitosti } \mathrm{k} \text { seberealizaci, sebeaktualizaci } \\
\text { a k rozvíjení podnikatelského myšlení }\end{array}$ \\
\hline $\begin{array}{l}\text { osvojení dovedností při používání a zacházení } \\
\mathrm{s} \text { vhodně zvolenými nástroji, pomůckami } \\
\text { a drobným nářadím; k přesnosti, } \\
\text { systematičnosti a vytrvalosti při plnění } \\
\text { pracovních úkolů }\end{array}$ & $\begin{array}{l}\text { vytrvalosti a soustavnosti při plnění zadaných } \\
\text { úkolů, } \mathrm{k} \text { uplatňování tvořivosti a vlastních } \\
\text { nápadů při pracovní činnosti a } \mathrm{k} \text { vynakládání } \\
\text { úsilí na dosažení kvalitního výsledku }\end{array}$ \\
\hline ------ & $\begin{array}{l}\text { poznání, že technika jako významná součást } \\
\text { lidské kultury je vždy úzce spojena s pracovní } \\
\text { činností člověka }\end{array}$ \\
\hline ------ & $\begin{array}{l}\text { autentickému a objektivnímu poznávání } \\
\text { okolního světa, k potřebné sebedůvěře, } \\
\text { k novému postoji a hodnotám ve vztahu k práci } \\
\text { člověka, technice a životnímu prostředí }\end{array}$ \\
\hline $\begin{array}{l}\text { dodržování hygienických a bez } \\
\text { pravidel při práci }\end{array}$ & -- \\
\hline
\end{tabular}

Tabulka č. 2: Cílové zaměreni vzdèlávaci oblasti ČSP 
Upravené OV 1. a 2. období tematického okruh ČSP, které odpovídají minimální doporučené úrovni v rámci podpůrných opatření, se od očekávaných výstupů tematického okruhu RVP ZV - LMP liší zejména:

- Zařazením některých nových tematických okruhů nebo jejich integrací do jiného, popríípadě přejmenováním.

- Nezařazením některých $\mathrm{OV}$, pro které není uveden výstup v minimální doporučené úrovni.

- Nekódováním některých $\mathrm{OV}$, které nejsou závazné a spíše představují nabídku vhodných specifických znalostí a dovedností.

- Upraveným kódováním pro snadnou identifikaci OV. (OV jsou označeny kódy, které obsahují zkratku vzdělávacího oboru, označení ročníku, číselné označení tematického okruhu, číslo určující pořadí očekávaného výstupu, písmeno „p“ slouží pro identifikaci upraveného OV na minimální doporučenou úroveň, např. ČSP-9-6-04p. Pokud písmeno „p“ není uvedeno, je OV totožný. V případě, že není uveden kód vůbec, má $\mathrm{OV}$ doporučující charakter.

Na 1. stupni byl zachován počet 4 tematických okruhů (Práce s drobným materiálem, Konstrukčni činnosti, Pěstitelské práce, Příprava pokrmi̊). Rozdíl je patrný pouze u druhého tematického okruhu, který je v RVP ZV (2016) nazván jako Konstrukční činnosti a v RVP - LMP (2005) byl uveden pod názvem Práce montážní a demontážní. Jedná se ale o zcela identické okruhy se stejnými očekávanými výstupy. Upravené OV těchto tematických okruhů jsou identické s OV př́lohy LMP.

$\mathrm{Na}$ 2. stupni byl vzdělávací obsah původně tvořen 7 tematickými okruhy (Práce s technickými materiály, Práce s ostatnimi materiály, Práce montážni a demontážní, Pěstitelské práce a chovatelství, Provoz a údržba domácnosti, Př́prava pokrmů, Svět práce). Aktuálně je podle RVP ZV (2016) tvořen 8 tematickými okruhy (Práce s technickými materiály, Design a konstruování, Pěstitelské práce a chovatelství, Provoz a údržba domácnosti, Př́prava pokrmů, Práce s laboratorní technikou, Využití digitálních technologii a Svět práce). Viz tabulka 3.

\begin{tabular}{|c|l|c|l|}
\hline \multicolumn{2}{|c|}{ RVP ZV - LMP (2005) } & \multicolumn{2}{c|}{ RVP ZV (2016) } \\
\hline 1 & Práce s technickými materiály & \multirow{2}{*}{1} & \multirow{2}{*}{ Práce s technickými materiály } \\
\hline 2 & Práce s ostatními materiály & & \\
\hline 3 & Práce montážní a demontážní & 2 & Design a konstruování \\
\hline 4 & Pěstitelské práce a chovatelství & 3 & Pěstitelské práce a chovatelství \\
\hline 5 & Provoz a údržba domácnosti & 4 & Provoz a údržba domácnosti \\
\hline 6 & Př́íprava pokrmů & 5 & Př́íprava pokrmů \\
\hline 7 & Svět práce & 6 & Svět práce \\
\hline \multirow{2}{*}{-} & ---- & 7 & Práce s laboratorní technikou \\
& & 8 & Využití digitálních technologí́ \\
\hline
\end{tabular}

\section{Tabulka č. 3: Tematické okruhy}

Do tematického okruhu Práce $\mathrm{s}$ technickými materiály bylo zařazeno kromě 6 původních výstupů 5 zdánlivě nových (rozlišuje různé druhy materiálů a zná jejich 
vlastnosti; zvoli vhodný pracovní postup v souladu s druhem zpracovávaného materiálu; správně vybere a použivá vhodné pracovni nástroje a pomůcky; dovede pracovni postupy k finálnímu výrobku; dodržuje technologickou kázen̆, zásady hygieny a bezpečnosti práce, poskytuje prvni pomoc př́ drobném úrazu). Tyto OV nejsou označeny kódem, nejsou tedy závazné a představují specifické znalosti a dovednosti, kterých lze dosáhnout i při př́ípadné úpravě výstupů. OV odpovídají očekávaným výstupům tematického okruhu Práce s ostatními materiály, který do upravených očekávaných výstupů již zařazen nebyl.

Tematický okruh Práce montážní a demontážní byl nahrazen tematickým okruhem Design a konstruování. Upravené OV však odpovídají původnímu tematickému okruhu Práce montážní a demontážní. Tematické okruhy Pěstitelské práce a chovatelství a Provoz a údržba domácnosti jsou zcela identické s původními. Tematický okruh Př́írava pokrmů zahrnuje stejné OV. Pouze u výstupu ČSP-9-5-02 je zdůrazněn fakt, že by se mělo jednat o jednoduché pokrmy. Do tematického okruhu Svět práce byly zařazeny na minimální úrovni dva OV (byl seznámen s právy a povinnostmi zaměstnanců a zaměstnavatelĩ; byl seznámen s možnostmi využití poradenské pomoci v př́ipadě neúspěšného hledání zaměstnáni), které byly původně uvedeny v př́loze LMP, avšak v neupravených OV RVP ZV uvedeny nejsou, proto mají pouze doporučující charakter. Jedná se přitom o výstupy, které jsou pro úspěšný vstup na trh práce a setrvání v něm zásadní, proto se jeví jako logické, aby byly tyto OV součástí tohoto tematického okruhu. Ostatní OV jsou stejné. Tematické okruhy Práce s laboratorní technikou a Využití digitálních technologií jsou novými okruhy. Práce s laboratorní technikou zahrnuje tyto OV: vybere a prakticky využivá pracovni postup konkrétni laboratorní činnosti a dodrží kázeñ při práci s př̀stroji, zařizením a pomůckami nutnými pro konáni pozorování, měrení, experimentu; dodržuje hygienu práce a zásady bezpečné práce s laboratorní technikou, př́slušnými nástroji, př́stroji a pomůckami při laboratornich činnostech; poskytne prvni pomoc pri úrazu v laboratoři. Okruh Využití digitálních technologií zahrnuje 5 OV: ovládá základní funkce vybraných digitálních zařizení, postupuje podle návodu k použití, při problémech vyhledá pomoc či expertní službu; propojuje vzájemně jednotlivá vybraná digitální zařizení; pracuje uživatelským způsobem s mobilními technologiemi v situacích, které odpovídaji okruhu jeho zájmù a potřeb; ošetrujuje digitálni techniku a chráni ji pred poškozenim; dodržuje základni hygienická a bezpečnostni pravidla a předpisy př́ práci s digitálni technikou a poskytne první pomoc při úrazu.

RVP ZV (2016) již neuvádí, na rozdíl od RVP - LMP (2005), že vzdělávací oblast Člověk a svět práce je jednou ze stěžejních oblastí v př́ípadě vzdělávání žáků s lehkým mentálním postižením. V části D (RVP ZV 2016), která se týká vzdělávání žáků se SVP, jsou uvedeny obecné a specifické požadavky, které je třeba zabezpečit a zohlednit pro úspěšné vzdělávání těchto žákủ. $Z$ obecných požadavků se jedná zejména o uplatňování diferenciovaného př́stupu a individualizovanou výuku; uplatňování systému podpůrných opatření; využívání prostředků alternativní a augmentativní komunikace a vhodných komunikačních systémů; úpravě organizace, forem, obsahu a metod výuky; prodloužení délky základního vzdělávání; formativní (průběžné) hodnocení a spolupráce s dalšími zainteresovanými subjekty. Ze specifických požadavků týkajících se žáků s LMP, které je třeba při edukaci zohlednit, se jedná o problémy v učení - čtení, psaní, počítání; nepřesné vnímání času; obtížné rozlišování podstatného a podružného; neschopnost pracovat s abstrakcí; snížená možnost učit se na základě zkušenosti, pracovat se změnou; problémy $\mathrm{s}$ technikou učení; problémy $\mathrm{s}$ porozuměním významu slov; krátkodobá pamět' 
neumožňující dobré fungování pracovní paměti, malá představivost; nedostatečná jazyková způsobilost, nižší schopnost číst a pamatovat si čtené, řešit problémy a vnímat souvislosti.

Mezi těmito obecnými a specifickými požadavky však nejsou uvedeny žádné činnosti ve smyslu rozvoje motoriky, manuální činnosti, pracovních dovedností, praktického nácviku, které jsou dominantou právě vzdělávací oblasti Člověk a svět práce. U žáků s lehkým mentálním postižením, ale i souběžným postižením, trvá nácvik běžných dovedností a utváření návyků mnohem delší dobu. Tento fakt RVP ZV - LMP (2005) zohledňoval navýšením časové dotace. Praktická činnost/nácvik je přitom nedílnou a převažující součástí speciálně pedagogických metod a terapeutických přístupů, které jsou uplatňovány v rámci edukace jedinců s MP. Rovněž nelze opomenout ani diagnostický potenciál. Metoda kompenzace rozvíjí osobnost převážně v mimointelektových oblastech. Metoda reedukace zkvalitňuje postižené funkce a metoda rehabilitace postihuje sociální dimenzi. Potenciál činnostních a pracovních terapií spočívá v zaměření se na manipulaci s materiálním okolím, která zahrnuje rukodělné činnosti a nácvik v oblasti praktického života. Přínos spočívá především v rozvoji těch dovedností a schopností, které bude člověk s MP ve svém životě skutečně potřebovat, a nebo lze prostřednictvím nich úspěšně kompenzovat diagnostikovaný deficit (Švarcová, 2011) (Müller, a kol., 2014) (Valenta, Müller, 2003). Svoji nezastupitelnou úlohu plní i ergoterapie s obdobnými cíli (Vodáková a kol. 2007).

RVP ZV v části D uvádí, že je nezbytné brát v úvahu to, že žáci se ve svých individuálních vzdělávacích potřebách a možnostech liší, a že účelem podpory by proto mělo být plné zapojení a maximální využití vzdělávacího potenciálu každého žáka s ohledem na jeho individuální možnosti a schopnosti, čehož lze dosáhnout právě prostřednictvím systému podpůrných opatření. Tento pětiúrovňový systém umožňuje na základě doporučení poradenského zařízení a splnění dalších náležitostí (podrobněji Vyhl. 27/2016 Sb.) vytvořit pro takového žáka IVP. Na jeho úrovni je pak možné v rámci podpůrných opatření (pro žáky s LMP od třetího stupně podpory) upravit OV stanovené ŠVP školy, př́ipadně upravit vzdělávací obsah, tedy vybrat jen některé učivo, popř. některý ze vzdělávacích oborů vzdělávacích oblastí nezařadit vůbec a nahradit je obsahem jiného. To se následně promítne i do upraveného RUP. Navíc lze za určitých okolností zařadit z disponibilní časové dotace do IVP žáka i předměty speciálně pedagogické péče a pedagogickou intervenci $\mathrm{v}$ závislosti na stupni přiznané podpory (podrobněji Př́loha č. 1 vyhlášky č. 27/2016 Sb.). U žáka se zrakovým deficitem by se mohlo jednat např. o orientaci v prostoru, psaní na Pichtově psacím stroji. U žáka s LMP by se mohlo jednat např. o rozvoj hrubé a jemné motoriky, praktický nácvik. RVP ZV uvádí, že by díky této variabilitě měl být zajištěn soulad mezi vzdělávacími požadavky a skutečnými možnostmi žáků, čímž by vzdělávání mělo směřovat k dosažení osobního maxima každého žáka.

\section{Možné perspektivy}

V podmínkách základních škol se může negativní dopad projevit zejména v nedostatku aprobovaných pedagogických pracovníků (Janu, Podlahová, Vitásek, 2016) (Hašková, Bánesz, 2015), nedostatečné metodické podpoře ze strany poradenských zařízení, popř. dalších subjektů a zvýšené administrativě v souvislosti s naplňováním proinkluzivních opatření, např. Plán pedagogické podpory (PPP), Individuální vzdělávací plán (IVP). To se pak může odrážet $\mathrm{v}$ koncipování a realizaci individuálně upravené výuky podle IVP 
nejen v této vzdělávací oblasti. RVP ZV (2016) uvádí, že nutné úpravy obsahu a realizace výuky budou předmětem metodické podpory, a že pedagogickým pracovníkům bude v této souvislosti zajištěna metodická podpora formou dalšího vzdělávání. Národní institut dalšího vzdělávání (NIDV), organizace zřizována MŠMT, za tímto účelem připravil na svých webových stránkách rozsáhlou nabídku kurzů a školení pro rok 2016/2017. Nabídka je zaměřena zejména na obecnou implementaci proinkluzivních př́stupů ve vzdělávání. Didaktické aspekty týkající se konkrétních vzdělávacích oblastí jsou tak spíše předmětem individuální konzultační podpory ze strany NIDV. Metodickou podporu ze strany krajů prostřednictvím programových nabídek Zařízení pro další vzdělávání pedagogických pracovníků a středisek služeb školám, lze naopak označit, na základě porovnání aktuálních programových nabídek jednotlivých zařízení, za naprosto nedostatečnou. Možnost metodického vedení a podpory ze strany poradenských pracovišt' je limitována jejich kapacitou, která je prozatím nedostatečná. Na to upozorňuje i Výroční zpráva ČŠI (VZ ČŠI 2015/2016), ve které je uvedeno, že s ohledem na očekávanou masivnější inkluzi je třeba zajistit posílení týmů školních poradenských pracovišt' o specialisty, protože odlišné vzdělávací potřeby žáků s LMP se promítnou až v IVP takového žáka. To s sebou nese nadbytečnou administrativní zátěž a nutnost metodické opory.

RVP ZV bylo dlouhodobě vytýkáno zejména ze strany pedagogické praxe, že je nejednoznačný $\mathrm{v}$ popisu úrovně očekávaných výstupů a dosahované kvality výsledků vzdělávání. Na to upozorňovala v roce 2011 i Národní ekonomická Rada vlády ČR, která ve své zprávě uvedla, že učitelé často nevědí, $\mathrm{k}$ jakým znalostem a dovednostem mají žáky dovést. Bez standardů a na ně navazujících evaluačních a diagnostických nástrojů mají učitelé velmi ztíženou roli v praktické implementaci kurikulární reformy (VZ ČŠI 2015/2016). V tomto ohledu lze pozitivně hodnotit snahu MŠMT, NÚV, NIDV a dalších odborníků, díky nimž $\mathrm{k}$ vytvoření Standardů základního vzdělávání právě pro vzdělávací oblast Člověk a svět práce došlo. Tyto Standardy obsahují komplexní ilustrativní úlohy, které vycházejí z běžné školní praxe a na kterých jsou demonstrovány, na minimální úrovni, indikátory k očekávaným výstupům daného tematického okruhu. S ohledem na začlenění očekávaných výstupů na minimální doporučené úrovni, a tím zvýšených požadavků na plánování a realizaci edukace ze strany pedagogických pracovníků, existuje reálné riziko, že se budou pedagogičtí pracovníci bez upravených Standardů ZV potýkat s problémem, jak implementovat a naplnit kurikulární reformu v praxi, např. jak u žáků zjišstovat dosahovanou kvalitu OV na minimální úrovni. ČŠI v této souvislosti poukazuje na neurčitost úpravy očekávaných výstupů a způsobu jejich ověřování, kdy s ohledem na SVP žáka (spodní hranice LMP, souběžné postižení více vadami apod.) nebude dosažení minimální úrovně mnohdy reálné (VZ ČŠI 2015/2016).

Dalším již zmiňovaným rizikem je to, s jakou časovou dotací bude ve školní praxi vzdělávací oblast ČSP realizována. S ohledem na dlouhodobé zkušenosti ZŠ, jejichž třídy, oddělení nebo studijní skupiny jsou zřízeny podle $§ 16$ (dřívější ZŠP), lze předpokládat, že $\mathrm{v}$ rámci úprav ŠVP bude disponibilní časová dotace použita mimo jiné $\mathrm{k}$ posílení právě těch vzdělávacích oblastí, kterých se úprava RVP ZV nejvíce dotkla, tedy Člověk a zdraví a Člověk a svět práce. U ZŠ, které nejsou zř́zeny podle § 16 (běžné ZŠ), lze předpokládat problém $\mathrm{s}$ možným sladěním odlišných učebních plánů $\mathrm{v}$ jedné tř́ídě, tedy $\mathrm{v}$ rozdílené časové dotaci jednotlivých předmětů. Mohlo by se např́klad jednat o situace, kdy žák 1 . stupně vzdělávaný podle IVP bude mít uvedenou časovou dotaci pro vzdělávací oblast ČSP 10 hodin a žák bez IVP pouze 5 hodin. V takovém prrípadě vyvstává řada nejasností, 
např. jak bude zajištěna efektivní výuka pro všechny žáky ve třídě? Bude př́padná podpora ze strany dalšího pedagogického pracovníka (zpravidla asistenta pedagoga) dostatečná a bude asistent pedagoga schopen vést individualizovanou formu výuky v souladu s požadavky IVP? Nedojde k omezení využívání odborných učeben, jsou-li k dispozici? Problém se sladěním odlišných učebních plánů a mnohdy i absence zkušeností se vzděláváním žáků s LMP se může promítnout do časové dotace vzdělávací oblasti ČSP v IVP takového žáka. Ke snížení počtu hodin Vzdělávacího oboru ČSP, který přímo směřuje $\mathrm{k}$ úspěšnému uplatnění se na trhu práce, $\mathrm{v}$ souvislosti se zrušením př́lohy LMP, uplatňovala ČŠI (8. záŕí 2015, 10. listopadu 2015, 8. února 2016) zásadní připomínky. Dále upozorňovala na řadu komplikací, které mohou spočívat právě ve sladění odlišných učebních plánů v jedné tř́idě a zvýšené administrativní zátěži (VZ ČŠI 2014/2015) (VZ ČŠI 2015/2016).

O nejasné koncepci $\mathrm{v}$ oblasti technického vzdělávání svědčí i výrok MŠMT z 15. ledna 2015. „Účinná a důsledná výchova $k$ volbě povolání žákio základnich škol vyžaduje úpravu problematiky Člověk a svět práce v Rámcovém vzdělávacím programu pro základni vzděláváni (RVP ZV) na podporu polytechnického vzdèláváni a rozvoje podnikavosti na druhém stupni základni školy. “

\section{Průzkumné šetření}

Zavádění společného vzdělávání je dlouhodobou záležitostí. Cílem průzkumného šetření proto není vyvrátit nebo potvrdit platnost některého z výše uvedených rizik, ale spíše postihnout aktuálnost a komplikovanost alespoň jednoho z nich. Konkrétně s jakou časovou dotací byla, je a pravděpodobně bude zajištěna výuka vzdělávací oblasti ČSP na 1. stupni ZŠ zřízených podle $\S 16$ (dřívější ZŠP) před a po zrušení přílohy č. 2 upravující vzdělávání žáků s LMP a jaké okolnosti výši časové dotace ovlivňují a mohou ovlivnit.

$\mathrm{Na}$ základě analýzy získaných dat z 11 škol na území JČK lze konstatovat, že před zrušením př́ilohy upravující vzdělávání žáků s LMP byla časová dotace vzděl. oboru ČSP na 1 . stupni $\pm 15,8$ hodin, to bylo o 0,8 hodiny více, než stanovil dnes již neplatný RUP a o 10,8 hodin více, než stanovuje aktuální RUP. Současná, respektive předpokládaná, časová dotace po vytvoření nového UP školy pro tuto oblast je $\pm 13,6$ hodin. To je o 2,2 hodin méně, než stanovoval dnes již neplatný RUP a o 8,6 hodin více, než uvádí aktuální RUP.

Dvě školy číslo 11,12 , viz Tabulka 4 , které již vytvořily nový ŠVP v souladu s RVP ZV, snížily původní časovou dotaci z 15 na 10 hodin a z 18 na 12 hodin. V průměru tedy na 11 hodin, což je o 6 hodin více než stanovuje platný RUP, ale o 4 hodiny méně než stanovil dnes již neplatný RUP. Škola číslo 11 přitom z celkové disponibilní časové dotace (DČD) 16 hodin posílila předmět matematika z 20 hodin na 23 hodin, což je o 1 hodinu více, než uváděl původní RUP; předmět informatika z 1 na 2 hodiny, což je shodné s původním RUP; předmět tělesná výchova z 10 na 15 hodin, což je rovněž shodné s původním RUP a předmět pracovní vyučování z 5 na 12 hodin, což je o 3 hodiny méně, než připouštěl původní RUP. Škola číslo 12 posílila z DČD předmět český jazyk z 33 hodin na 36 hodin, což je o 3 hodiny více, než uváděl původní RUP; předmět matematika z 20 hodin na 23 hodin, což je o 1 hodinu více, než uváděl původní RUP; předmět informatika z 1 na 2 hodiny, což je shodné s původním RUP; předmět tělesná výchova z 10 na 13 hodin, což je oproti původnímu RUP o 2 hodiny méně a předmět pracovní vyučování z 5 na 10 hodin, což je o 5 hodiny méně, než uváděl původní RUP. V př́ípadě obou škol byl 
z DČD posílen nejvíce předmět pracovní vyučování. Na otázku, proč právě tento předmět, poukazovaly obě ředitelky zejména na důležitost praktického uplatnění těchto žáků v návaznosti na trh práce a učební obory. Dále uváděly počty žáků, kteří se z 9 . ročníků hlásí do učebních oborů. Ředitelka školy číslo 12 mimo jiné uvedla, že jakákoliv motorická činnost, at' už $\mathrm{v}$ rámci tělesné výchovy nebo práce $\mathrm{v}$ dílně, má výrazně zklidňující a motivující potenciál pro tento druh postižení. Obě školy se nacházejí ve větších městech, jsou tvořeny několika součástmi a při porovnání s ostatními, patř́ mezi ty největší. To mohlo mít na úpravu UP vliv.

Ze zbývajících 9 škol prozatím plánuje ponechat časovou dotaci beze změny 7 škol, které jsou uvedeny pod čísly $1-7$, viz Tabulka 4 . Současně ale připouští její možné snížení, rozhodně neplánují její posilování. Na otázku týkající se disponibilní časové dotace odpověděla ředitelka školy číslo 5: „Disponibilní hodiny se budeme snažit využít tak, aby byl náš učební plán univerzálně použitelný a bylo možno logicky a smysluplně organizovat výuku i za cenu většího počtu IVP. Snižení časové dotace u této oblasti proto nevylučujeme. Budeme si k tomu ale muset sednout. “ Ředitel školy číslo 2 uvedl: „Je jasné, že to bude všechno problém, hlavně pro naše žáky, takže asi bude třeba posilit hlavni predměty. Díky IVP máme ale možnost udělat si obrázek o tom, jak to žáci zvládnou, na co se zaměrit. Nemáme kam spěchat. Při tvorbě učebního plánu budeme vycházet právě z IVP. “"

Škola číslo 8 , viz Tabulka 4, plánuje snižit počet hodin z 15 na 5 a disponibilní časovou dotaci využít pro posílení jiných vzdělávacích oborů, konkrétně českého jazyka, matematiky, cizího jazyka, tělesné výchovy a výtvarné výchovy. Chce tak přibližit svůj učební plán co nejvíce školám, které nejsou zřizovány podle $\$ 16$. Díky tomu by pak prý neměla problém s př́ípadným zřízením dalších oddělení a studijních skupin zaměřených na jiný typ postižení, nap̌r. poruchy chování.

Škola číslo 9, viz tabulka 4, předpokládá snížení z 15 na 12 hodin. Disponibilní časovou dotaci plánuje využít na zavedení předmětu speciálně pedagogické péče logopedie, protože se na tento typ postižení v rámci své činnosti zaměřuje.

\begin{tabular}{|l|c|c|c|c|c|c|c|c|c|c|c|c|}
\hline \multirow{3}{*}{ Škola } & \multicolumn{9}{|c|}{ ŠVP podle RVP - LMP } & \multicolumn{6}{c|}{$\begin{array}{c}\text { SV podle RVP - ZV (Již mají nebo } \\
\text { mají v plánu vytvořit) }\end{array}$} \\
\cline { 2 - 13 } & \multicolumn{9}{|c|}{ 1. stupeň/ročník } \\
\cline { 2 - 14 } & 1. & 2. & 3. & 4. & 5. & $\sum$ & 1. & 2. & 3. & 4. & 5. & $\sum$ \\
\hline 1 & 2 & 2 & 3 & 4 & 4 & 15 & 2 & 2 & 3 & 4 & 4 & 15 \\
\hline 2 & 3 & 3 & 3 & 3 & 3 & 15 & 3 & 3 & 3 & 3 & 3 & 15 \\
\hline 3 & 4 & 4 & 3 & 3 & 4 & 18 & 4 & 4 & 3 & 3 & 4 & 18 \\
\hline 4 & 2 & 3 & 4 & 4 & 4 & 17 & 2 & 3 & 4 & 4 & 4 & 17 \\
\hline 5 & 3 & 3 & 3 & 3 & 3 & 15 & 3 & 3 & 3 & 3 & 3 & 15 \\
\hline 6 & 3 & 3 & 3 & 3 & 3 & 15 & 3 & 3 & 3 & 3 & 3 & 15 \\
\hline 7 & 3 & 3 & 3 & 3 & 4 & 16 & 3 & 3 & 3 & 3 & 4 & 16 \\
\hline 8 & 3 & 3 & 3 & 3 & 3 & 15 & 1 & 1 & 1 & 1 & 1 & 5 \\
\hline 9 & 2 & 2 & 3 & 4 & 4 & 15 & 2 & 2 & 2 & 3 & 3 & 12 \\
\hline 10 & 2 & 2 & 3 & 4 & 4 & 15 & 3 & 3 & 2 & 1 & 1 & 10 \\
\hline 11 & 3 & 3 & 4 & 4 & 4 & 18 & 2 & 2 & 2 & 3 & 3 & 12 \\
\hline$\sum$ hod. & 30 & 31 & 35 & 38 & 40 & 174 & 28 & 29 & 29 & 31 & 33 & 150 \\
\hline$\varnothing$ hod. & 2,7 & 2,8 & 3,1 & 3,4 & 3,6 & 15,8 & 2,5 & 2,6 & 2,6 & 2,8 & 3 & 13,6 \\
\hline
\end{tabular}




\section{Tabulka čislo 4: UP školy}

Z dotazníkového šetření a výpovědí ředitelů vyplývá, že jsou si vědomi významu a nezastupitelnosti této vzděl. oblasti, což se snaží při koncipování UP i nadále zohlednit. Zároveň ale poukazují na řadu faktorů, které je třeba brát v úvahu. Ty lze rozdělit na oblast změn vyplývajících z RVP ZV (např. zavedení dalšího cizího jazyka, problém se sladěním učebních plánů, riziko dosažení OV alespoň na minimální úrovni) a místní podmínky a možnosti školy (např. otázka transformace, rožšřření předmětu činnosti, sloučení škol, nízký zájem pedagogických pracovníků a žáků o výuku této vzdělávací oblasti).

Lze konstatovat, že školy i nadále považují vzdělávací oblast ČSP za důležitou, a proto ji plánují posílit, nebo ji již posílily navýšením počtu hodin z disponibilní časové dotace. Zároveň je ale patrná tendence i nadále nechat posílené nebo posílit jiné oblasti a vypořádat se tak s problémem zásadního snížení časové dotace pro tuto oblast z 15 na 5 hodin. Z toho vyplývá, že po zrušení prrílohy upravující vzdělávání žáků z LMP nebude na většině škol reálné ponechat časovou dotaci, kterou měly uvedenou ve svých dnes již neplatných ŠVP.

Na snížení časové dotace u této vzdělávací oblasti má tedy zásadní vliv postupné zavádění společného vzdělávání (proinkluzivních př́ístupů), což se na kurikulární úrovni odrazilo zrušením RVP - LMP.

\section{Diskuze}

Je zřejmé, že společné vzdělávání s sebou přináší řadu perspektiv, se kterými se $\mathrm{v}$ rámci postupného zavádění musí školy z důvodů legislativních změn vypořádat.

Z realizovaného průzkumného šetření je patrné, že i školy stejného typu volí rozdílné strategie, prostřednictvím nichž se zaměřují na rozvoj KK žáků. Dále, že volba strategie je ovlivněna např. potenciálními možnostmi školy, její velikostí, smýšlením pedagogického sboru a dalšími aspekty, které v rámci průzkumného šetření nebyly zjišt'ovány. Pravděpodobně tak postupují i při zavádění konkrétních intervenčních opatření, např. pozice asistenta pedagoga, speciálního pedagoga, výběr kompenzačních a speciálně didaktických pomůcek. Celkový výsledek bude jistě ovlivněn i postojovými hodnotami a celou řadou dalších aspektů.

Otázce dopadu proinkluzivních přistupů, respektive jejich postupnému zavádění v podmínkách českých škol, ještě nebyla s ohledem na novost tématu, věnována dostatečná pozornost. Výše analyzované perspektivy, které vyplývají ze zrušení př́lohy LMP, proto mohou mít př́nos, co by pilotní sonda, díky níž by mohlo být provedeno smíšené převážně kvalitativní šetření, prostřednictvím něhož by mohla být seriózně zodpovězena např. tato otázka: Co znamená společné vzděláváni pro školu běžného typu a školu zřizenou podle § 16 a jak tyto školy dospívaji ke svému názoru na inkluzi, poprípadě jak tento názor modifikuji ve svých podmínkách?

Metodou př́padové studie by tak bylo možné popsat pojetí z hlediska konkrétní školy a zároveň alespoň rámcově porozumět tomu, jak si toto pojetí utvárí, např. v kontextu dalších faktorů. Jak uvádí Hendl (2016), výhodou kvalitativního př́ístupu je mimo jiné přirozená podmínka sociálního prostředí a získání podrobného vhledu do zkoumané problematiky. Inspiraci lze nalézt např. u Píšové, M. a kol. (2011), kteří se zabývali kurikulární reformou na gymnáziích. Právě tímto směrem se chceme ubírat. 


\section{Závěr}

Postupné zavádění společného vzdělávání vyústilo zrušením Přílohy upravující vzdělávání žáků s LMP. Pro školy to znamená úpravu nebo vytvoření nových ŠVP v souladu s RVP ZV(2016). V článku byly prostřednictvím obsahové analýzy popsány hlavní změny, které s sebou tato úprava pro vzdělávací oblast ČSP v RVP ZV (2016) přináší a které se promítnou do upravovaných nebo nově tvořených ŠVP. Jedná se o: úpravu časové dotace vzdělávací oblasti, změnu cílového zaměření, zařazení nových tematických okruhů, úpravu očekávaných výstupů, absenci specifického požadavku na praktickou činnost, zavedení systému podpůrných opatření.

Následnou komparací byly analyzovány některé z možných perspektiv, které mohou ovlivnit kvalitu dosahování KK u žáků s LMP. Jsou to: otázka počtu aprobovaných pedagogických pracovníků, nedostatečná metodická podpora ze strany poradenských zařízení, administrativní zátěž, absence upravených standardů pro ZV, otázka využití disponibilní časové dotace, zajištění podpory ze strany dalších pedagogických pracovníků.

V rámci průzkumného šetření bylo zjištěno, že školy zřizované podle $\S 16$ (dřivější ZŠP) jsou si vědomy významu vzdělávací oblasti ČSP, proto mají tendenci posílit sníženou časovou dotaci z 15 na 5 hodin pro 1. stupeň z DČD. Zároveň jsou ale nuceny řešit jiné aspekty. Konkrétně oblast změn vyplývajících z RVP ZV, místní podmínky a možnosti školy. Proto je pravděpodobné, že na většině škol nebude reálné ponechat časovou dotaci pro tuto vzdělávací oblast $\mathrm{v}$ té podobě, $\mathrm{v}$ jaké ji měly uvedenou v dnes již neplatných ŠVP.

\section{Literatura}

Částková, P., Kropáč, J., Plischke, J. (2016). Př́nos informálního a neformálního vzděláváni pro technické vzděláváni žáků základni školy. In Journal Technology and Information Education, č. 2/2016, vol. 8, s. 53-66. ISSN: 1803-537X.

ČŠI. (2015) Výroční zpráva za školní rok 2014/2015. Praha: ASTRON. ISBN: 80-8808706-9.

ČŠI. (2016). Výroční zpráva za školní rok 2015/2016. Praha: ASTRON. ISBN: 978-8088087-09-0.

ČŠI. (2010). Výroční zpráva za školní rok 2009/2010. Praha. ISBN nemá.

Dostál, J., Prachagool, V. (2016). Technické vzdělávání na křižovatce - historie, současnost a perspektivy. In Journal Technology and Information Education, č. 2/ 2016, vol. 8, s. 5-24. ISSN: 1803-537X.

Dostál, J., Kožuchová, M. (2016). Badatelský přistup v technickém vzdělávání. Olomouc: Univerzita Palackého v Olomouci. ISBN 978-80-244-4913-5.

European Commission. (2016). The new Skills Agenda for Europe. [cit. 2016-11-02] Dostupné na: <http://ec.europa.eu/social/main.jsp?catId=1223>

Hašková, A., Bánesz, G. (2015). Technika na základných školách - áno alebo nie. Praha: Verbum. ISBN 978-80-87800-31-7.

Hendl, J. (2016). Kvalitativni výzkum: základní metody a aplikace. Praha: Portál. ISBN 978-80-262-0982-9.

Janu, M., Podlahová, L., Vitásek, P. (2016). K pojetí obsahu technického vzdělávání na základní škole se zaměřením na výuku o dřevě. In Journal Technology and Information Education, č. 2/2016, vol. 8, s. 169-180. ISSN: 1803-537X. 
Kol. autorů. (2004). Didaktika technických předmětů, vybrané kapitoly. Olomouc: Univerzita Palackého v Olomouci. ISBN 80-244-0848-1.

Mach, P., Simbartl, P. \& Krotký, J. (2015). World of Work - Aktivita 1 Průzkum Vyhodnoceni dotaznikového šetreni. ZČU v Plzni. Dostupné na: < http://www.world-ofwork.eu/sites/default/files/documents/Research_report_CZ.pdf>

MŠMT. (2016). RVP ZV - Př́loha č. 1 k Opatření ministryně školství, mládeže tělovýchovy, kterým se mění Rámcový vzdělávací program pro základní vzdělávání, čj. MSMT-28603/2015. Praha.

Müller, O. (2014). Terapie ve speciální pedagogice. Praha: Grada. ISBN 978-80-247$4172-7$.

NÚV. (2001). Memorandum o celoživotním učení (Zpravodaj, př́loha II). [cit. 2016-1106] Dostupné

na:

<http://www.nuv.cz/uploads/Periodika/ZPRAVODAJ/2001/ZP01PIIa.pd>

Píšová, M., Kostková, K., \& Vlček, P. (2011). Kurikulární reforma na gymnáziích: př́ípadové studie. In T. Janík, P. Knecht, \& S. Šebestová (Eds.), Smišený design v pedagogickém výzkumu: Sborník př́spěvků z 19. výročni konference České asociace pedagogického výzkumu (s. 24- 30). Brno: Masarykova univerzita. [cit. 2016-08-05] Dostupné na: http://www.ped.muni.cz/capv2011/sbornikprispevku/pisovakostkovavlcek.pdf Švarcová I. (2011). Mentální retardace: vzdělávání, výchova, sociálni péče. Praha: Portál. ISBN 978-80-7367-889-0.

UNECE. (2005). Strategie pro vzdèlávání pro udržitelný rozvoj [cit. 2016-09-06] Dostupné na: <https://www.unece.org/fileadmin/DAM/env/esd/strategytext/strategyinczech.pdf> Valenta, M., Müller, O. Psychopedie. (2004). Praha: Parta. ISBN 80-7320-063-5. Vodáková, J. a kol. (2007). Speciální pracovni výchova a ergoterapie. Praha: UK. ISBN 978-80-7290-322-1.

VÚP. (2005). Rámcový vzdělávací program pro základní vzdělávání - př́loha upravujicí vzděláváni žáků s lehkým mentálním postižením. Praha: TAURIS. ISBN 80-87000-02-1. Vyhl. 27 ze dne 21. ledna 2016 o vzdělávání žáků se speciálními vzdělávacími potřebami a žákủ nadaných. In: Sbirka zákonů. 28.1.2016, částka 107. PDF online. ISSN 1211-1244. Dostupné na Portálu veřejné správy ČR.

ZK 561/2004 Sb. o předškolním, základním, středním, vyšším odborném a jiném vzdělávání (školský zákon). In: Sbirka zákonů. 10.11.2004, částka 190. PDF online. ISSN 1211-1244. Dostupné na Portálu veřejné správy ČR.

ZK 178 ze dne 20. dubna 2016, kterým se mění zákon č. 561/2004 Sb., o předškolním, základním, středním, vyšším odborném a jiném vzdělávání (školský zákon), ve znění pozdějších předpisů. In: Sbirka zákonů. 8.6.2016, částka 687. PDF online. ISSN 12111244. Dostupné na Portálu veřejné správy ČR. 